\title{
The Role of Emotional Intelligence and Self-Efficacy in Developing Entrepreneurial Career Intentions
}

\author{
Erin McLaughlin \\ Missouri Western State University
}

The purpose of this study was to empirically examine the relationships among the constructs of entrepreneurial career intentions, emotional intelligence, and entrepreneurial self-efficacy. The author used structural equation modeling with a sample of 218 business students to test the hypotheses. The results suggest that (1) the greater the perception of emotional intelligence the greater the entrepreneurial career intentions and (2) the greater the entrepreneurial self-efficacy the greater the entrepreneurial career intentions. The author then discusses practical applications and areas for future research.

Keywords: Emotional Intelligence, Self-efficacy, Career Intentions, Entrepreneurship

\section{INTRODUCTION}

The field of entrepreneurship represents an increasingly dynamic productive force in the economy and resides at the forefront of adaptation and the growth of new markets (Gavron, Cowling, Holtham, \& Westall, 1998). Small firms in general and new firms in particular contribute significantly to the economic growth and prosperity for well-developed countries (Birch, 1987). Such economic growth is a direct result of an increase in the size of existing firms as well as the creation of new firms. Creating new economic entities, or entrepreneurship, is vital to the progression of organizations and economies (Aldrich, 1999). Entrepreneurial activity is a vital component of national economic growth and development; it promotes innovation, fosters job creation, and encourages the global competitiveness of firms and countries (Bednarzik, 2000; Kim, Aldrich, \& Keister, 2003). The formation of new businesses also leads to social and economic stratification in an economy (Haltiwanger \& Krizan, 1999).

The present economic situation has resulted in organizational downsizing and regular periods of unemployment, which have induced growing numbers of people to aspire to self-employment. From an individual's perspective, creating a new firm is often developed as part of the entrepreneur's personal life strategy as a means of earning a living (Littunen, 2000). For many individuals, self-employment represents both an escape from life in traditional organizational bureaucracies and an opportunity to generate greater personal wealth (Walker \& Webster, 2007). Self-employment offers opportunities for flexibility, independence, profits, and personal recognition.

In a theoretical discussion of the psychology of new venture creations, Shaver and Scott (1991) emphasized that new ventures emerge because of deliberate choices made by individuals. Additional research has focused on using perceived feasibility and desirability to predict entrepreneurship (Krueger, Reilly, \& Carsrud, 2000). These additional studies have found support for the models developed by Ajzen 
(1991, 1985) and Shapero (1982), which used perceived feasibility and desirability to predict entrepreneurial intentions.

The purpose of this study is to empirically test the relationships among career intentions, emotional intelligence, and self-efficacy in the entrepreneurial sector. Previous research by Boyd and Vozikis (1994) proposed a theoretical model where self-efficacy is an important antecedent to the subsequent intentions and behavior of entrepreneurs. Additionally, Chen, Greene, and Crick (1998) empirically showed that entrepreneurial self-efficacy was positively related to students' intentions to pursue entrepreneurial work roles. Nonetheless, previous research to date has not examined the critical role of emotional intelligence as an antecedent to entrepreneurial intentions and behaviors.

This study makes four major contributions to entrepreneurial career research. First, it provides a theoretical explanation, grounded in Ajzen's Theory of Planned Behavior (Ajzen, 1985), for the influence of perceived behavioral control variables on entrepreneurial intentions. Second, by using an entrepreneurial lens, this study can confirm prior research findings on the role of self-efficacy in career intentions, specifically in the entrepreneurship context. Third, this study has the ability to contribute to the emotional intelligence research stream as a tool for identifying, understanding, and ultimately predicting career behavior. Finally, from a more practical standpoint, this study has the ability to make major contributions to the development of entrepreneurial curricula.

\section{Ajzen's Theory of Planned Behavior}

The Theory of Planned Behavior was developed from the previous work of Fishbein and Ajzen (1975) and the Theory of Reasoned Action (TRA). This theory (TRA) suggested that people who evaluated the proposed behavior with a positive attitude and felt that significant others wanted them to perform the behavior would be more motivated to ultimately perform the intended behavior. TRA argued behavioral intention as the outcome variable, but several researchers critiqued the link between intention and actual behavior, stating that intention could not be an exclusive determinant of behavior without conditions (Sheppard, Hartwick, \& Warshaw, 1988). Thus, in 1985, Ajzen proposed the Theory of Planned Behavior, which added the new component of "perceived behavioral control." This component overcame many of the criticisms of TRA by going beyond the prediction of behavioral intentions to actual behavior.

The Theory of Planned Behavior has three motivational factors-also known as "pillars" or "antecedents" - that influence behavior. The first, attitude (or personal attitude), is the degree to which an individual has a positive or negative personal valuation about the intended behavior (Ajzen, 2001; Autio, Keeley, Klofsten, Parker, \& Hay, 2001; Kolvereid, 1996). The second, subjective norms, measures the perceived social support of performing (or not performing) the intended behavior. The final pillar, which is the focus of this paper, is perceived behavioral control. This construct refers to an individual's perception of the ease or difficulty of fulfilling the intended behavior.

\section{Perceived Behavioral Control}

Perceived behavioral control includes more than just the feeling of being able - it also includes the perception of controllability regarding the intended behavior. Perception is concerned not with the skills one possesses but with an individual's judgments about what can be done with those skills (Kickul et al., 2009). According to Krueger and Dickson (1994), it is often the perceptions that are seen as more important than the actual skills when seeking the determinants of behavior. Therefore, an individual's perceptions about self-efficacy and emotional intelligence - not their actual ability level-define their beliefs of whether or not the entrepreneurial endeavor is feasible. It is this perception of entrepreneurial self-efficacy and/or emotional intelligence that actually leads to a greater likelihood of pursuing an entrepreneurial career.

Perceived behavioral control deals with the presence or absence of requisite resources and opportunities: it is an individual's perceived control in executing a specific behavior (Ajzen, 1991). Carr and Sequeira (2007) suggested that perceived behavioral control includes not only perception of resource availability but also perceived ease or difficulty in completing a task. Control beliefs are influenced by 
past experience as well as second-hand information about the behavior from other important or significant individuals (Ajzen, 1991). According to the Theory of Planned Behavior, the perception of greater opportunities and resources, or fewer anticipated obstacles and impediments, leads to greater perceived behavioral control.

\section{Emotional Intelligence}

The concept of emotional intelligence (EI) has gained the attention of researchers and practitioners alike (e.g., Weisenger, 1998; Abraham, 1999). Practitioners have realized that employees can no longer be perceived as biological machines that are capable of leaving their feelings, norms, and attitudes at home when they go to work. The study of emotions has been a heavily researched topic in areas such as sociology and psychology, but has more recently moved into organizational behavior research as a result of an increased emphasis in studying how emotions relate to actions. Management researchers are embracing the concept of emotional intelligence due to its applicability to workplace issues such as performance, job satisfaction, absenteeism, organizational commitment, intentions, and leadership issues (Rozell, Pettijohn, \& Parker, 2002).

The roots of EI stem from the concept of "social intelligence," first acknowledged by Thorndike in 1920. Thorndike defined social intelligence as "the ability to understand and manage men/women, boys/girls - to act wisely in human relations" (1920: 231). Gardner (1993) followed up on Thorndike's work and identified seven intelligence domains in his development of Multiple Intelligence Theory. In Gardner's (1993) work on multiple intelligences, he recognized interpersonal and intrapersonal intelligences as two imperative aspects of the social intelligence outlined by Thorndike (1920). Specifically, intrapersonal intelligence was "one's intelligence in dealing with oneself, and thus the ability to symbolize complex and highly differentiated sets of feelings" (Thorndike, 1920: 239), whereas interpersonal intelligence was "one's intelligence in dealing with others and the ability to notice and make distinctions among other individuals and, in particular, among their moods, temperaments, motivations, and intentions" (Thorndike, 1920: 239).

Emotional intelligence, as outlined by Mayer and Salovey (1997), contains the following four branches:

1. Identifying emotions. Identifying or perceiving emotions is the initial and most basic of the four branches. It is the nonverbal reception and expression of emotion and includes several skills such as the ability to identify feelings, express emotions accurately, and to differentiate between real and phony emotional expressions (Mayer, Salovey, \& Caruso, 2000). Furthermore, emotions tend to appear in facial expressions, tone of voice, body language, and even works of art (Salovey \& Mayer, 1990). Emotions researchers, evolutionary biologists, specialists in nonverbal behavior, and others have made tremendous strides in understanding how human beings recognize and express emotions. They have pointed out that emotional expressions evolved in animal species as a form of critical social communication and that the facial expressions for happiness, sadness, anger, and fear are universally recognizable in humans (Mayer \& Salovey, 1997).

2. Facilitating emotions. Mayer and Salovey (1990) identified the second area as using emotions to facilitate thought. This is the capacity of emotions to enter into and guide the cognitive system and to promote thinking. The emotional facilitation of thought includes the ability to use emotions to redirect attention to important events and to generate emotions that facilitate decision-making (Salovey \& Mayer, 1990).

3. Understanding emotions. This dimension is an assessment of an individual's ability to understand emotions and to reason with emotional knowledge (Kerr, Garvin, Heaton, \& Boyle, 2006). An individual who understands the complexities of emotions can better handle challenging situations and the ability to comprehend the cause of emotions gives insight into 
human nature, particularly regarding relationships (Salovey \& Mayer, 1990). Understanding emotions is the ability to comprehend complex emotions, the ability to recognize the causes of emotions, and the ability to understand relationships among emotions (Mayer et al., 2000). Therefore, fully understanding emotions involves the comprehension of the meaning of emotions coupled with the capacity to reason about those meanings, and it is central to the group of emotionally intelligent skills (Mayer \& Salovey, 1997).

4. Regulating emotions. The highest branch of the emotional intelligence model (Mayer \& Salovey, 1990) involves managing both your own feelings and the emotions of others. Managing emotions includes the ability to remain aware of one's emotions, even those that are unpleasant, the ability to determine whether an emotion is clear or typical, and the ability to solve emotion-laden problems without necessarily suppressing negative emotions (Mayer et al., 2000). The "using emotions" branch is the most advanced emotional intelligence ability within the model; thus, it has the potential for the greatest impact on performance functions (George, 2000). Furthermore, the ability to regulate emotions can assist in the creation of effective strategies to achieve enhanced performance.

Thus, psychology professors John D. Mayer and Peter Salovey are the true founders of emotional intelligence. In their first academic paper (Mayer \& Salovey, 1990: 187), the formal definition of emotional intelligence emerged as "the ability to perceive emotions, to access and generate emotions so as to assist thought, to understand emotions and emotional knowledge, and to effectively regulate emotions so as to promote emotional and intellectual thought." In their theory of emotional intelligence, Mayer and Salovey implied that two distinct mental processes, thinking and feeling, actually work together to focus on the extent to which emotions inform people's cognitive abilities and the extent to which emotions are cognitively managed.

It is a widely held view that emotional intelligence skills can be taught, learned, and/or acquired (e.g., Boyatzis, Stubbs, \& Taylor, 2002; D'Intino, Goldsby, Houghton, \& Neck, 2007; O'Boyle, Humphrey, Pollack, Hawver, \& Story, 2011; Shepherd, 2004). Organizations and social referents, such as role models, can assist in developing emotional intelligence competencies when leading by example and providing appropriate training (Akers \& Porter, 2003). For instance, Beaujean, Davidson, and Madge (2006) suggested that when people become conscious of their own inhibiting mindsets, they are more capable of learning additional emotionally intelligent behaviors. Guidance from the role models that exemplify the desired mindset enables the self-discovery process. Additionally, insights into these mindsets occur through feedback, reflection, and stories about the successes and failures of other social referents (Beaujean et al., 2006). Perceptions of emotional intelligence abilities affect entrepreneurial behaviors. Specifically, employees with greater self-perceived emotional intelligence exhibit a greater tolerance to stress and environmental stressors (Nikolaou \& Tsaousis, 2002). Because the ability to handle stress in an entrepreneurial role is essential, individuals with a self-perception of high emotional intelligence can better use their emotional regulation skills to their advantage. Nikolaou and Tsaousis (2002) explained that employees high in emotional intelligence exhibit a greater tolerance for environmental stressors, are better able to identify emotions like frustration and, subsequently, regulate such feelings to reduce stress and increase their entrepreneurial behavior. In addition, individuals with greater self-perceived emotional intelligence tend to have greater affectivity (Zampetakis, Beldekos, \& Moustakis, 2009), which permits entrepreneurial behaviors such as creativity and proactivity (Amabile, Barsade, Mueller, \& Staw, 2005).

\section{Entrepreneurial Self-Efficacy}

The theory of self-efficacy stems from the work of Bandura $(1986,1997)$ on social learning theory and represents the belief in one's ability to execute an intended act and the belief that one is personally capable of implementing or engaging in an intended behavior. More specifically, self-efficacy is defined 
as "...belief in one's capabilities to mobilize the motivation, cognitive resources, and courses of action needed to meet given situational demands..." (Wood \& Bandura, 1989: 364. Self-efficacy pertains to beliefs regarding one's capabilities for the successful implementation of specific goals or tasks, which can be varied and extend to multiple areas within a specific task domain (Bandura, 1986, 1997; Gist, 1987). In the context of the present study, the focus is on entrepreneurial self-efficacy (ESE), which is the perceived capability of an individual regarding the performance of functions necessary in effectively accomplishing specific entrepreneurial roles or tasks (Boyd \& Vozikis, 1994). Stated differently, ESE is a specific form of efficacy beliefs targeted at entrepreneurial behaviors.

Widespread discussions have evolved regarding the self-efficacy construct and its implications for management, specifically entrepreneurship (Gist, 1987; Boyd \& Vozikis, 1994; Wood \& Bandura, 1989). Theorists have proposed that self-efficacy plays an instrumental role in the formation of career preferences, intentionality, and performance (Boyd \& Vozikis, 1994; Gartner, 1989; Krueger \& Brazeal, 1994; Scherer et al., 1989). For example, Boyd and Vozikis (1994) proposed that self-efficacy influences the development of entrepreneurial intentions and the probability of new venture creation.

Krueger and Brazeal (1994) identified a variable they called perceived venture self-efficacy in their model of entrepreneurial intentions. With an emphasis on the desirability and feasibility of new venture creation, they argued that someone's judgment is grounded in self-perception of the ability to execute tasks associated with planning and launching a new firm. Therefore, as an individual's confidence in undertaking entrepreneurial tasks increases, the perception about the feasibility of the venture becomes more positive (Krueger \& Brazeal, 1994). Stated differently, individuals are more naturally inclined to choose situations, or occupations, in which they anticipate greater personal control and to avoid situations where they anticipate less personal control (Wood \& Bandura, 1989). Ultimately, people choose their career paths by assessing their personal capabilities against the occupational requirements. Entrepreneurial self-efficacy is developed over time and influenced by internal and external factors like upbringing, economic circumstances, personality, and values (Cox, Mueller, \& Moss, 2002).

Entrepreneurial self-efficacy is commonly viewed as a predictor of entrepreneurial intentions and behaviors (Boyd and Vozikis, 1994; Krueger and Brazeal, 1994; Scherer et al., 1989; Chen, Greene, \& Crick, 1998; Zhao, Seibert, \& Hills, 2005). Kickul, Gundry, Barbosa, \& Whitcanack (2009: 442) proclaimed that "there is sufficient and robust research to assert the relationship between self-efficacy and intentionality." The overarching idea across the literature is that individuals with greater self-efficacy tend to have greater entrepreneurial intentions (e.g., Chen et al., 1998; De Noble, Jung, \& Ehrlich, 1999; Jung, Ehrlich, De Noble, \& Baik, 2001; Scott \& Twomey, 1988). Throughout the literature, new venture creation is a purposeful and intentional career choice (e.g., Bird, 1988; Boyd \& Vozikis, 1994; Krueger \& Brazeal, 1994). Numerous contextual and individual factors influence entrepreneurship as a career choice, but entrepreneurial self-efficacy has been emphasized as a key antecedent (Boyd \& Vozikis, 1994; Krueger \& Brazeal, 1994).

\section{Entrepreneurial Intentions}

Entrepreneurial intention is defined by Bird (1988) as the conscious and intended act of new venture creation. It is a state of mind directing and guiding the behaviors or actions of the entrepreneur toward the development, and ultimately the implementation, of the business concept. Entrepreneurial intentions are the first step in an extensive process of venture creation (Lee \& Wong, 2004) and start-up intentions are the necessary precursor to entrepreneurial behaviors (Fayolle, Gailly, \& Lassas-Clerc, 2006; Kolvereid, 1996; Linan \& Chen, 2009). According to the Theory of Planned Behavior, entrepreneurial intentions represent the effort exerted by an individual to perform a specific entrepreneurial behavior (Linan \& Chen, 2009).

Over the last three decades, research has supported the reliability of intentions in predicting actual behavior (Shaver \& Scott, 1991; Krueger, 1993; Kickul et al., 2009). In fact, in many studies, intention is considered to be the single best predictor of behavior (Ajzen, 1991, 2001; Fishbein \& Ajzen, 1975). Furthermore, intentions are greatly affected by individuals' perceptions of their own abilities and skills (i.e., self-efficacy, Bird, 1988; Krueger et al., 2000; Kickul et al., 2009). Scott and Twomey (1988) 
suggested that a business idea and self-perception ultimately lead to an entrepreneurial career preference. Additional research by Dyer (1994) identified three key antecedents to career preference, which included entrepreneurial factors, social aspects, and economic issues. Figure 1 provides the proposed structural model of entrepreneurial intentionality.

\section{FIGURE 1}

\section{STRUCTURAL EQUATION MODEL OF LINKAGES AMONG EMOTIONAL INTELLIGENCE, ENTREPRENEURIAL SELF-EFFICACY, AND ENTREPRENEURIAL INTENTIONS}

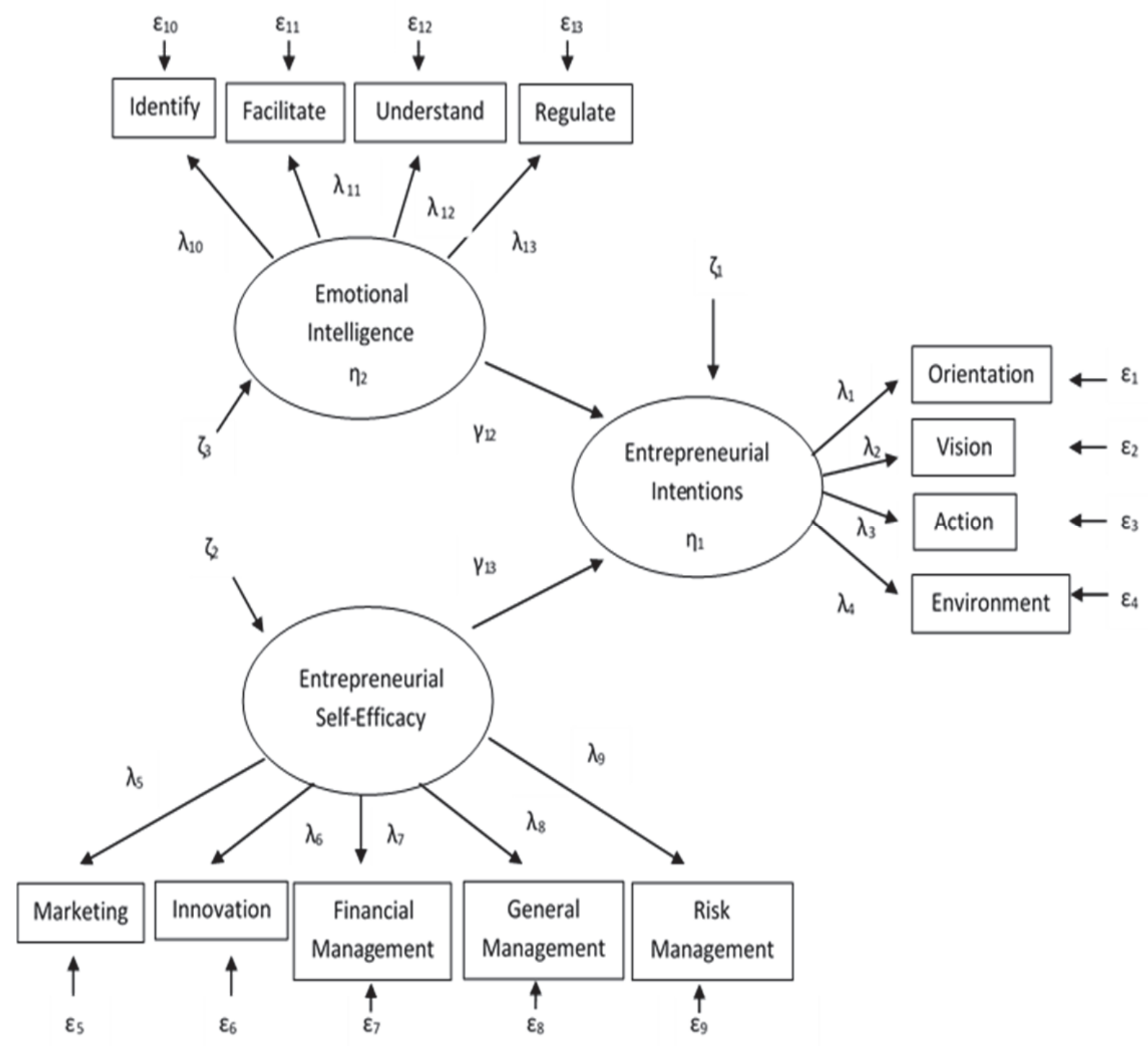

Hypothesis 1: The greater the perception of emotional intelligence, the greater the entrepreneurial intentions.

Hypothesis 2: The greater the perception of entrepreneurial self-efficacy, the greater the entrepreneurial intentions. 


\section{METHODS}

\section{Sample and Procedure}

Subjects for this study included 218 undergraduate students (63\% men and 37\% women) at a large public university in the Southwest United States. A survey was administered during the Entrepreneurship course taught in the College of Business. The course is required of all Business students with a major or minor in Entrepreneurship, but also taken by students from other business disciplines and colleges across the university. College of Business students represented 52\% of the respondents while the rest came from other colleges. The mean age of the sample was 23.65 years $(\mathrm{SD}=3.29)$ ranging from 20 to 39 years. Students came from different academic levels (2\% sophomores, $15 \%$ juniors, $82 \%$ seniors, $1 \%$ graduate). Because over $98 \%$ were juniors, seniors, and graduate students, it was expected that they were involved in career choice decisions.

\section{Measures}

Emotional intelligence was operationalized in terms of the subdimensions of (1) ability to identify emotions, (2) ability to facilitate emotions, (3) ability to understand emotions, and (4) ability to regulate emotions based on Groves, McEnrue, and Shen (2008). Entrepreneurial self-efficacy was estimated by addressing the subdimensions of (1) marketing, (2) innovation, (3) financial management, (4) general management, and (5) risk management based on measures by Chen, Greene, and Crick (1998). Entrepreneurial intentions were gauged by assessing dimensions related to starting a business, (1) orientation, (2) vision, (3) action, and (4) environment; the measure was developed by Carr and Sequeira (2006). All scales were anchored with 5-point Likert-type response categories. As seen in Table 1, all three scales were previously addressed with psychometric scrutiny and demonstrated satisfactory levels of convergent, discriminant, and nomological validities in the source studies provided.

TABLE 1

MEASUREMENT SUMMARY: CONTENT, APPROACH, ORIGINS, AND PAST PERFORMANCE

\begin{tabular}{|c|c|c|c|}
\hline Constructs & Content & Reliability & Sample Scale from Present Study \\
\hline $\begin{array}{l}\text { Entrepreneurial } \\
\text { likely Intentions }\end{array}$ & $\begin{array}{l}\text { Perceived likelihood of an } \\
\text { entrepreneurial career }\end{array}$ & & not likely at all...........very \\
\hline $\begin{array}{l}\text { Orientation } \\
(I=4)\end{array}$ & & $\begin{array}{c}0.88 \\
(0.80)\end{array}$ & $\begin{array}{l}\text { How likely do you think it is that you will } \\
\text { someday start your own business? }\end{array}$ \\
\hline $\begin{array}{l}\text { Vision } \\
(\mathrm{I}=2)\end{array}$ & & $(0.72)$ & How likely are you to start a corporation? \\
\hline $\begin{array}{l}\text { Action } \\
(\mathrm{I}=2)\end{array}$ & & $\begin{array}{c}0.75 \\
(0.82)\end{array}$ & $\begin{array}{l}\text { How likely are you to start saving money to } \\
\text { invest in your business idea? }\end{array}$ \\
\hline $\begin{array}{l}\text { Environment } \\
(\mathrm{I}=2)\end{array}$ & & $\begin{array}{c}0.72 \\
(0.79)\end{array}$ & $\begin{array}{l}\text { How likely are you to create an environment } \\
\text { where people are excited about your idea? }\end{array}$ \\
\hline $\begin{array}{l}\text { Emotional } \\
\text { Intelligence }\end{array}$ & $\begin{array}{l}\text { Perceived ability to identify, } \\
\text { facilitate, understand, and use } \\
\text { emotions }\end{array}$ & & strongly disagree......... strongly agree \\
\hline $\begin{array}{l}\text { Identify } \\
(\mathrm{I}=6)\end{array}$ & & $\begin{array}{c}0.88 \\
(0.74)\end{array}$ & $\begin{array}{l}\text { I can accurately identify a range of emotions } \\
\text { I feel from day to day. }\end{array}$ \\
\hline $\begin{array}{l}\text { Facilitate } \\
(\mathrm{I}=6)\end{array}$ & & $\begin{array}{c}0.81 \\
(0.72)\end{array}$ & $\begin{array}{l}\text { I listen to feelings of other people in } \\
\text { establishing priorities. }\end{array}$ \\
\hline $\begin{array}{l}\text { Understand } \\
(\mathrm{I}=6)\end{array}$ & & $\begin{array}{c}0.75 \\
(0.71)\end{array}$ & $\begin{array}{l}\text { I can usually detect subtle changes in the } \\
\text { emotions of my friends. }\end{array}$ \\
\hline $\begin{array}{l}\text { Regulate } \\
(\mathrm{I}=6)\end{array}$ & & $\begin{array}{c}0.72 \\
(0.73)\end{array}$ & $\begin{array}{l}\text { I notice when someone is very caring and } \\
\text { compassionate toward others. }\end{array}$ \\
\hline
\end{tabular}




\begin{tabular}{|c|c|c|c|}
\hline Constructs & Content & Reliability & Sample Scale from Present Study \\
\hline $\begin{array}{l}\text { Entrepreneurial } \\
\text { Self-Efficacy }\end{array}$ & $\begin{array}{l}\text { Perceived ability to perform } \\
\text { the functions necessary to } \\
\text { accomplish specific } \\
\text { entrepreneurial tasks }\end{array}$ & & $\begin{array}{l}\text { How certain do you feel you can... } \\
\text { not certain at all............very certain }\end{array}$ \\
\hline $\begin{array}{l}\text { Marketing } \\
(\mathrm{I}=4)\end{array}$ & & $\begin{array}{c}0.73 \\
(0.74)\end{array}$ & Conduct market analysis? \\
\hline $\begin{array}{l}\text { Innovation } \\
(\mathrm{I}=4)\end{array}$ & & $\begin{array}{c}0.85 \\
(0.76)\end{array}$ & Come up with new venture ideas? \\
\hline $\begin{array}{l}\text { Financial } \\
\text { Management } \\
(\mathrm{I}=4)\end{array}$ & & $\begin{array}{c}0.88 \\
(0.85)\end{array}$ & Set and meet market share goals? \\
\hline $\begin{array}{l}\text { Management } \\
(\mathrm{I}=4)\end{array}$ & & $\begin{array}{c}0.77 \\
(0.73)\end{array}$ & Manage time by setting goals? \\
\hline $\begin{array}{l}\text { Risk Management } \\
(\mathrm{I}=4)\end{array}$ & & $\begin{array}{c}0.79 \\
(0.75)\end{array}$ & Manage a company to reduce overall risk? \\
\hline
\end{tabular}

Reliabilities: Numbers above the parentheses are reliabilities achieved in the source studies; numbers within the parentheses denote reliabilities achieved in this study. For all constructs, convergent, discriminant, and nomological validities were demonstrated in the source studies. All responses were obtained using 5-point Likert-type scales.

\section{Measure Assessment}

A total battery of 56 scale items was used across all constructs in this study. The coefficient alphas for entrepreneurial intentions were as follows: orientation (.80), vision (.72), action (.82), and environment (.79). For the construct of emotional intelligence, the factors identify, facilitate, understand, and regulate returned coefficient alphas of $0.74,0.72,0.71$, and 0.73 , respectively; suggesting that generally acceptable reliabilities were achieved. The coefficient alphas for entrepreneurial self-efficacy were: marketing (.74), innovation (.76), financial management (.85), general management (.73), and risk management (.75). All reliability coefficients were larger than .70 , which is the benchmark frequently specified for reliability (Nunnally, 1978).

Validity is defined by Hair, Black, Babin, Anderson, and Tatham (2006) as the extent to which research data are accurate. A major advantage of using SEM is its ability to assess the construct validity of a proposed measurement theory. Construct validity is the extent to which a set of measured items actually reflects the theoretical latent construct those items are designed to measure and, thus, deals with the accuracy of measurement (Hair et al., 2006). Evidence of construct validity is composed of the following four components: (1) convergent validity, (2) discriminant validity, (3) nomological validity, and (4) face validity. Validity was tested using single-factor structure test diagnostics (Table 2) from a structural equations modeling perspective using LISREL. Reliability and factor structure diagnostics (i.e., $\mathrm{X}^{2}$, RMSR, GFI, AGFI, and NFI) were all generally supportive and fell within the acceptable ranges. 
TABLE 2

MEASUREMENT SCALES: RELIABILITY AND FACTOR STRUCTURE (LISREL) DIAGNOSTICS

Factor Structure Diagnostics

\begin{tabular}{lccccccc}
\hline \multicolumn{1}{c}{ Construct } & Reliability & $\chi^{2}$ & df & RMSR & GFI & AGFI & NFI \\
\hline Identify Emotions & 0.80 & 106.51 & 13 & 0.08 & 0.86 & 0.69 & 0.87 \\
Facilitate Emotions & 0.72 & 86.57 & 13 & 0.07 & 0.82 & 0.65 & 0.76 \\
Understand Emotions & 0.82 & 135.81 & 13 & 0.07 & 0.75 & 0.76 & 0.78 \\
Regulate Emotions & 0.79 & 93.67 & 13 & 0.10 & 0.87 & 0.71 & 0.74 \\
Marketing & 0.74 & 16.87 & 4 & 0.05 & 0.96 & 0.85 & 0.81 \\
Innovation & 0.72 & 8.47 & 4 & 0.02 & 0.98 & 0.92 & 0.96 \\
Financial Management & 0.71 & 15.49 & 4 & 0.06 & 0.97 & 0.87 & 0.91 \\
General Management & 0.73 & 81.34 & 13 & 0.08 & 0.84 & 0.67 & 0.74 \\
Risk Management & 0.74 & 18.22 & 4 & 0.06 & 0.97 & 0.90 & 0.96 \\
Orientation & 0.76 & 16.78 & 4 & 0.05 & 0.98 & 0.93 & 0.98 \\
Vision & 0.85 & 0.78 & 2 & 0.02 & 0.99 & 0.98 & 0.98 \\
Action & 0.73 & 2.19 & 2 & 0.02 & 0.99 & 0.96 & 0.98 \\
Environment & 0.75 & 0.76 & 2 & 0.02 & 0.99 & 0.99 & 0.99 \\
\hline
\end{tabular}

Convergent validity is the extent to which different assessment methods concur in their measurement of the same trait (i.e., construct); ideally, these values should be moderately high (Byrne, 1998). The average variance extracted (AVE) among a set of construct items is a summary indicator of convergence and can be calculated by using the standardized loadings: $A V E=\left(\sum \Lambda \mathrm{i} 2\right) / \mathrm{n}$, where $\Lambda$ represents the standardized factor loadings and the $i$ is the number of items. Therefore, for $n$ items, AVE is computed as the total of all squared standardized factor loadings (squared multiple correlations) divided by the number of items. This is the average squared factor loading. AVE of 0.5 or higher is a good rule of thumb suggesting adequate convergence; AVE of less than 0.5 indicates that on average more error remains in the items than variance explained by the latent factor structure imposed on the measure. AVE ranged from .425 (Emotional Intelligence) to .539 (Entrepreneurial Intentions), suggesting generally acceptable levels of convergence (Table 3). Reliability is also an indicator of convergent validity and coefficient alpha remains a commonly applied estimate, though it may understate reliability. Construct reliability is similar to Cronbach's alpha, but CR is based on the variance/covariance matrix, where alpha is based on the correlational matrix. Construct reliability is computed as $\left(\sum \Lambda \mathrm{i}\right) 2 /\left(\sum \Lambda \mathrm{i}\right) 2+\left(\sum \delta \mathrm{i}\right)$ and shown in Table 3. A general rule of thumb for construct reliability (CR) is that it should be greater than or equal to 0.7 , and the CR values for this study ranged from .748 (Emotional Intelligence) to .784 (Entrepreneurial SelfEfficacy). 


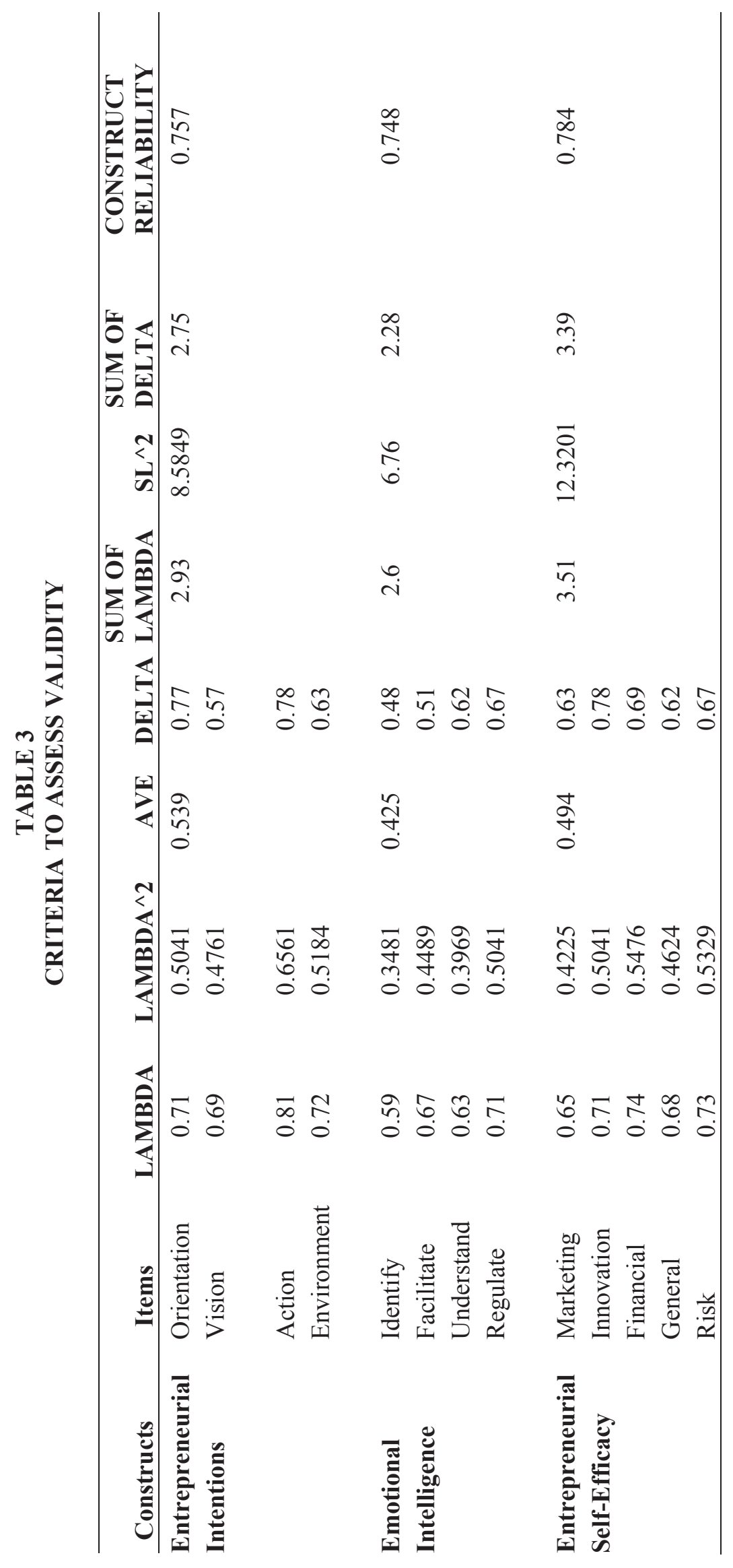

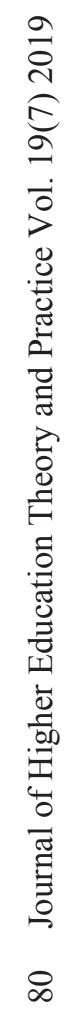


Discriminant validity is the extent to which a construct is truly distinct from other constructs; ideally, these values should demonstrate minimal convergence. High discriminant validity provides evidence that a construct is unique and captures some phenomena other measures do not. Discriminant validity is presented in Table 4, where the reliabilities are contrasted with intertrait correlations of the study variables. All 77 of the correlations were lower than the reliability estimates, satisfying the essential requirement of discriminant validity (Churchill, 1995). Based on previous theoretical development, the psychometric performance, convergent, and discriminant validity, the scale items were averaged to form composite scores before use in the hypothesis testing. 


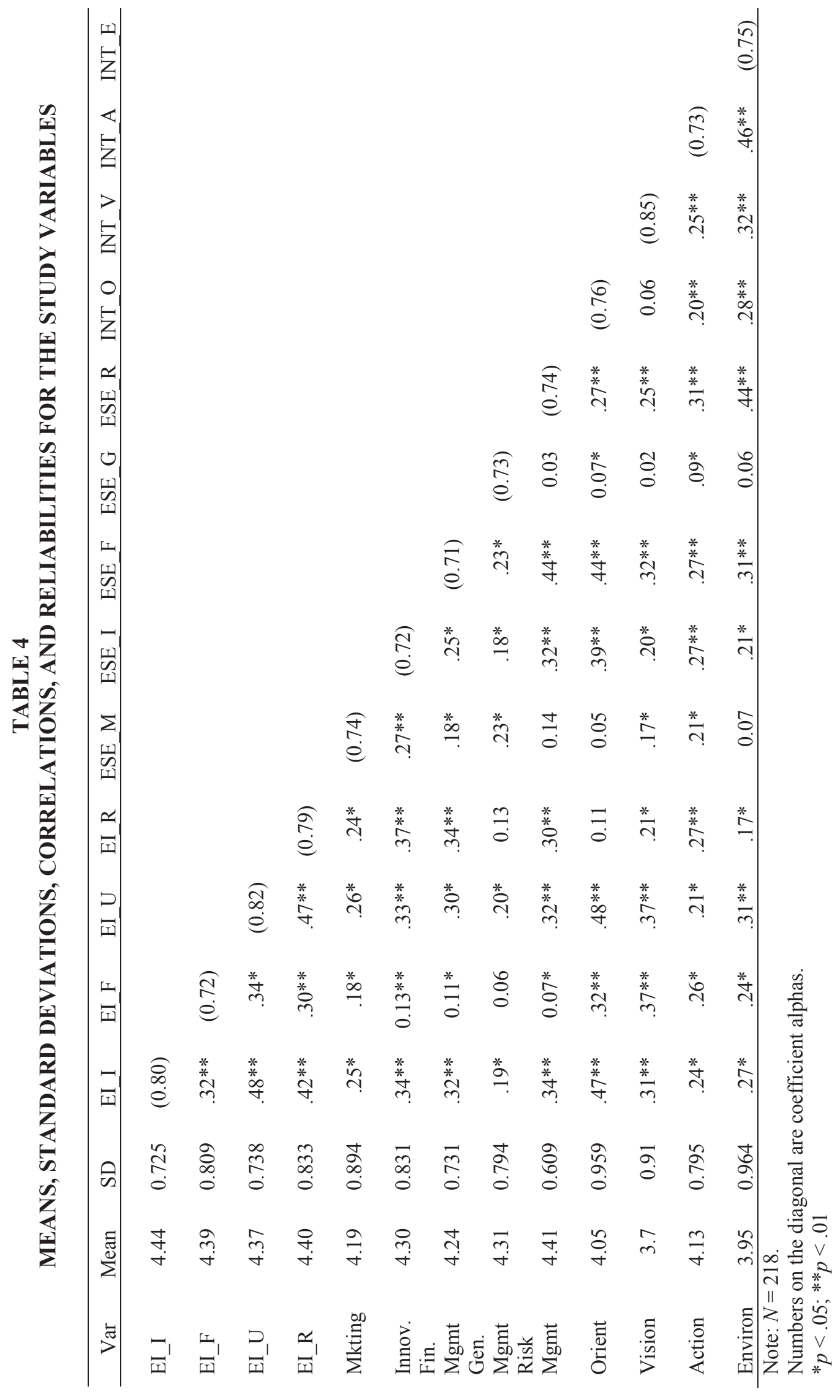

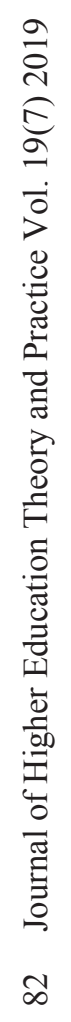




\section{RESULTS}

As presented in Figure 1, the hypothesized relationships among emotional intelligence, entrepreneurial self-efficacy, and entrepreneurial intentions were converted into a set of structural equations and tested using LISREL software. The results are reported in Table 5. The consistently high and statistically significant $\lambda_{i}$ values provide support for the composite measures used in the hypothesis testing. The proposed theoretical structure also appears to hold up well under empirical scrutiny according to the following global-fit indices: $\chi^{2}=696.94 ; \mathrm{df}=63 ; p<.05$; RMSR $=.041$; GFI $=.92$; AGFI $=.87$; $\mathrm{NFI}=.89$; and RMSEA $=.08$. All values meet the goodness-of-fit criteria suggested by $\mathrm{Hu}$ and Bentler (1999).

TABLE 5

TEST OF HYPOTHESES: ESTIMATES OF STRUCTURAL EQUATIONS MODEL

\begin{tabular}{|c|c|c|c|c|c|}
\hline & Parameters & Path & & Standardized Estimate & $t$-value \\
\hline \multicolumn{6}{|l|}{ Endogenous } \\
\hline Entrepreneurial & Orientation & $\lambda(1)$ & & 0.71 & 36.3 \\
\hline \multirow[t]{3}{*}{ Intentions } & Vision & $\lambda(2)$ & & 0.69 & 34 \\
\hline & Action & $\lambda(3)$ & & 0.81 & Set to 1.00 \\
\hline & Environment & $\lambda(4)$ & & 0.72 & 34.8 \\
\hline \multicolumn{6}{|l|}{ Exogenous } \\
\hline Emotional & Identify & $\lambda(10)$ & & 0.58 & 26.11 \\
\hline \multirow[t]{3}{*}{ Intelligence } & Facilitate & $\lambda(11)$ & & 0.64 & 28.63 \\
\hline & Understand & $\lambda(12)$ & & 0.63 & 26.46 \\
\hline & Regulate & $\lambda(13)$ & & 0.71 & Set to 1.00 \\
\hline Entrepreneurial & Marketing & $\lambda(5)$ & & 0.65 & 28.83 \\
\hline \multirow[t]{4}{*}{ Self-Efficacy } & Innovation & $\lambda(6)$ & & 0.71 & 32.75 \\
\hline & Financial & $\lambda(7)$ & & 0.74 & 31.02 \\
\hline & General & $\lambda(8)$ & & 0.68 & 27.57 \\
\hline & Risk & $\lambda(9)$ & & 0.72 & Set to 1.00 \\
\hline \multicolumn{6}{|l|}{ Structural Relation } \\
\hline EI-->Ent Intent & & $\gamma(1,2)$ & $\mathrm{H} 1$ & 0.21 & 3.04 \\
\hline ESE-->Ent Intent & & $\gamma(1,3)$ & $\mathrm{H} 2$ & 0.46 & 9.46 \\
\hline \multicolumn{6}{|l|}{ Global Model Fit } \\
\hline Chi-Square & & & & 696.94 & \\
\hline Df & & & & 63 & \\
\hline p-value & & & & 0.0235 & \\
\hline RMSR & & & & 0.041 & \\
\hline GFI & & & & 0.92 & \\
\hline AGFI & & & & 0.87 & \\
\hline NFI & & & & 0.89 & \\
\hline RMSEA & & & & 0.08 & \\
\hline
\end{tabular}


Overall, as inferred from the $\gamma_{i}$ values representing the causal paths in Figure 1, the results provide significant support for the hypothesized relationships. Hypothesis 1, relating perceptions of emotional intelligence to entrepreneurial career intentions, was supported $\left(\gamma_{12}=.21, p<.05\right)$. The greater the perception of emotional intelligence (identifying, facilitating, understanding, and regulating emotions) the greater the entrepreneurial intentions. Hypothesis 2, relating perceptions of entrepreneurial self-efficacy to entrepreneurial career intentions was also supported $\left(\gamma_{13}=.46, p<.05\right)$. The greater the perception of entrepreneurial self-efficacy (the ability to complete entrepreneurial tasks of marketing, innovation, financial management, general management, and risk management) the greater the entrepreneurial career intentions. All hypothesized relationships were statistically significant and directionally correct. For goodness-of-fit indexes on the hypothesized relationships, see Table 6.

\section{TABLE 6 GOODNESS-OF-FIT INDEXES FOR STRUCTURAL EQUATION MODELS}

\begin{tabular}{lcccccc}
\hline \multicolumn{1}{c}{ Model } & $\mathrm{X}^{\wedge} 2(\mathrm{df})$ & RMSR & GFI & AGFI & NFI & RMSEA \\
\hline Saturated Model with all paths & $696.94(63)$ & 0.041 & 0.92 & 0.87 & 0.89 & 0.08 \\
EI --> Entrepreneurial Intentions & $130.65(18)$ & 0.056 & 0.97 & 0.92 & 0.95 & 0.10 \\
ESE --> Entrepreneurial Intentions & $150.27(25)$ & 0.023 & 0.99 & 0.97 & 0.98 & 0.08 \\
\hline
\end{tabular}

\section{DISCUSSION}

The primary goal of this study was to explore the effects of emotional intelligence and entrepreneurial self-efficacy on career preference. By using entrepreneurship as the intended career of choice, the results of this study confirm findings of prior research on entrepreneurial self-efficacy and intentions (Sequeira, Mueller, \& McGee, 2007; Zhao, Seibert, \& Hills, 2005). Using a sample of students from diverse educational backgrounds and enrolled in an Entrepreneurship course, the findings show that individuals with high entrepreneurial self-efficacy are more likely to have intentions and the desire to start a new business (H1). Unique to this study, emotional intelligence was also found to have a significantly positive relationship with entrepreneurial intentions $(\mathrm{H} 2)$; thus, the need to further study emotional intelligence as an individual difference that influences career preferences is evident.

From a research standpoint, the contributions of this study are abundant. First, this study has the potential to refresh career research on the role of self-efficacy in investigations of entrepreneurial intentions. Second, this study contributes to the emotional intelligence research stream. Because EI has such strong roots and ties to social intelligence, theoretically differentiating the two constructs continues to challenge researchers (Gardner, 1993); nonetheless, the emotional intelligence perspective continues to be another tool that scholars can use in their efforts to identify, understand, and predict employment behaviors. Therefore, this study contributes to the understanding of EI and assists in the building of a nomological network to support this stream of research.

Several practical implications for the study of these relationships warrant further discussion as well. These findings imply that entrepreneurial career intentions may be enhanced by (1) increasing students' emotional intelligence capabilities and (2) boosting students' confidence for success in an entrepreneurial career. Congruent with the implications of Boyatzis et al. (2002) and Zhao et al. (2005), it is recommended that entrepreneurship education incorporate as many diverse types of learning experiences related to the promotion of greater entrepreneurial self-efficacy as possible. Many entrepreneurship courses emphasize entrepreneurial management and planning skills, but overlook entrepreneurial skills like emotional control, innovation, and confidence. The skills taught tend to be technical, lacking attention to cognition and belief systems of the entrepreneur (Kickul \& D'Intino, 2005). Thus, emotional competencies and self-efficacy should be considered when educators design and assess entrepreneurship course objectives as these constructs can change and improve with attention, training, and practice (Boyatzis et al., 2002; D’Intino et al., 2007; O'Boyle et al., 2011; Shepherd, 2004). The findings of this 
study, therefore, support the creation of supportive classrooms that focus on key entrepreneurial career skills and allow students to launch businesses in a competitive climate.

In summary, while theoretical models of entrepreneurship suggest that an individual's intention to create a new venture is a strong predictor of eventual entrepreneurial action, ambiguity still resides in identifying the factors that influence the likelihood of entrepreneurial career intentions and nascent behavior (Sequeira et al., 2006). This study developed and tested hypotheses about how emotional intelligence and self-efficacy are related to entrepreneurial career intentions. The results show that emotional intelligence and entrepreneurial self-efficacy both have strong positive relationships with entrepreneurial career intentions. A higher level of emotional intelligence leads to an increased likelihood of an entrepreneurial career choice as does self-efficacy.

\section{ACKNOWLEDGEMENT}

This research was funded by the Logan Grant at Missouri Western State University.

\section{REFERENCES}

Abraham, R. (1999). Emotional intelligence in organizations: A conceptualization. Genetic, Social, and General Psychology Monographs, 125(2), 209-224.

Ajzen, I. (1985). From intentions to actions: A theory of planned behavior, in Kuhl, J., and Beckmann, J., eds., Action Control: From Cognition to Behavior, Springer-Verlag, Berlin, 11-39.

Ajzen, I. (1987). Attitudes, traits, and actions - Dispositional prediction of behavior in personality and social psychology. Advances in Experimental Social Psychology, 20, 1-63.

Ajzen, I. (1991). Theory of planned behavior. Organizational Behavior and Human Decision Processes, $50,179-211$.

Ajzen, I. (2001). Nature and operation of attitudes. Annual Review of Psychology, 52, 27-58.

Ajzen, I. (2002). Perceived behavioral control, self-efficacy, locus of control, and the theory of planned behavior. Journal of Applied social Psychology, 32(4), 665-683.

Akers, M. D., \& Porter, G. L. (2003). Your EQ skills: Got what it takes? Journal of Accountancy, 195.

Aldrich, H.E. (1999). Organizations Evolving. Sage Publications, London.

Amabile, T. M., Barsade, S. G., Mueller, J. S., \& Staw, B. M. (2005). Affect and creativity at work. Administrative Science Quarterly, 50, 367-403.

Autio, E., Keeley, R. H., Klofsten, M., Parker, G. G. C., \& Hay, M. (2001). Entrepreneurial intent among students in Scandinavia and in the USA. Enterprise and Innovation Management Studies, 2(2), 145-160.

Bandura, A. (1986). Social foundations of thought and action: A social cognitive theory. Englewood Cliffs, NJ: Prentice Hall.

Bandura, A (1992), Exercise of personal agency through the self-efficacy mechanism, in Schwarzer, R. (Ed.), Self-Efficacy: Thought Control of Action, Hemisphere, Washington, DC.

Bandura, A. (1997). Self-efficacy belief: The exercise of control. New York: Freeman and Co.

Beaujean, M., Davidson, J., \& Madge, S. (2006). The 'moment of truth' in customer service. McKinsey Quarterly, 1, 62-73.

Bednarzik, R. W. (2000). The role of entrepreneurship in U.S. and European job growth. Monthly Labour Review, 6, 3-16.

Birch, D., 1987. Job creation in America. New York, NY: The Free Press.

Bird, B. (1988). Implementing entrepreneurial ideas: The case for intention, Academy of Management Review, 13(3) 442-453.

Boyatzis, R. E., Stubbs, E. C., \& Taylor, S. N. (2002). Learning Cognitive and Emotional Intelligence Competencies through Graduate Management Education. Academy of Management Learning \& Education, 1(2), 150-162. 
Boyd, N. G., \& Vozikis, G. S. (1994). The influence of self-efficacy belief on the development of entrepreneurial intentions and actions. Entrepreneurship: Theory \& Practice, 18(4), 63-77.

Byrne, B. M. (1998). Structural Equation Modeling with LISREL, PRELIS, and SIMPLIS: Basic Concepts, Applications, and Programming. Erlbaum: New Jersey.

Carr, J. C., \& Sequeira, J. M. (2007). Prior family business exposure as intergenerational influence and entrepreneurial intent: A Theory of Planned Behavior approach. Journal of Business Research, 60, 1090-1098.

Chen, C. C., Greene, P. G., \& Crick, A. (1998). Does entrepreneurial self-efficacy belief distinguish entrepreneurs from managers? Journal of Business Venturing, 13, 293-316.

Churchill, Jr., \& Gilbert, A. (1995). Marketing Research: Methodological Foundations, 6th ed., The Dryden Press, Hindsdale, IL.

Cox, L. W., Mueller, S. L., \& Moss, S. E. (2002). The impact of entrepreneurship education on entrepreneurial self-efficacy. International Journal of Entrepreneurship Education, 1(2), 220-245.

Dennis, W. J. (1999). Business starts and stops. San Francisco: National Federation of Independent Business Education Foundation.

DeNoble, A. F., Jung, D., \& Ehrlich, S. B. (1999). Entrepreneurial self-efficacy: The development of a measure and its relationship to entrepreneurial action. In R. D. Reynolds, W. D. Bygrave, S. Manigart, C. M. Mason, g. D. Meyer, H. J. Sapienza, et al. (Eds.), Frontiers of entrepreneurship research. Waltham, MA: P\&R Publications Inc., 73-87.

D'Intino, R. S., Goldsby, M. G., Houghton, J. D., \& Neck, C. P. (2007). Self-Leadership: A process for entrepreneurial success. Journal of Management History, 14(1), 39-57.

Dyer, W. (1994). Toward a theory of entrepreneurial careers. Entrepreneurship: Theory and Practice, 19(2), 7-22.

Fayolle, A., Gailly, B., \& Lassas-Clerc, N. (2006). Assessing the impact of entrepreneurship education programmes: A new methodology. Journal of European Industrial Training, 30(9), 701-720.

Fishbein, M., \& Ajzen, I. (1975). Belief, attitude, intention and behavior: An introduction to theory and research. New York: Addison-Wesley.

Gardner, H. (1993). Multiple Intelligences: The Theory in Practice. New York: Basic Books.

Gartner, W. B. (1989). Some suggestions for research on entrepreneurial traits and characteristics. Entrepreneurship Theory and Practice, 14, 27-37.

Gavron, R., Cowling, M., Holtham, G., \& Westall, A. (1998). The Entrepreneurial Society. London: Institute for Public Policy Research, Central Books.

George, J. M. (2000). Emotions and leadership: The role of emotional intelligence. Human Relations, 53, 1027-1055.

Gist, M. E. (1987). Self-efficacy belief: Implications for organizational behavior and human resource management. Academy of Management Review, 12, 472-485.

Groves, K. S., McEnrue, M. P., \& Shen, W. (2008). Developing and measuring the emotional intelligence of leaders. Journal of Management Development, 27(2), 225-250.

Hair, J. F., Black, W. C., Babin, B. J., Anderson, R. E., \& Tatham, R. L. (2006). Multivariate Data Analysis. Pearson-Education, Uppersaddle River: New Jersey.

Haltiwanger, J., \& Krizan, C. J. (1998). Small business and job creation in the United States: The role of new and young businesses. University of Maryland Department of Economics, College Park, Maryland.

Hu, L., \& Bentler, P. M. (1999). Cutoff criteria for fit indexes in structure analysis: Conventional criteria versus new alternatives. Structural Equation Modeling, 6, 1-55.

Jung, D. I., Ehrlich, S. B., DeNoble, A. F., \& Baik, K. B. (2001). Entrepreneurial self-efficacy and its relationship to entrepreneurial action: A comparative study between the US and Korea. Management International, 6(1), 41-54.

Kerr, R., Garvin, J., Heaton, N., \& Boyle, E. (2006). Emotional intelligence and leadership effectiveness. Leadership \& Organization Development Journal, 27(4), 265-279. 
Kickul, J., \& D'Intino, R. (2005). Measure for measure: modeling entrepreneurial self-efficacy onto instrumental tasks within the new venture creation process. New England Journal of Entrepreneurship, 8(2), 39-48.

Kickul, J., Gundry, L. K., Barbosa, S. D., \& Whitcanack, L. (2009). Intuition versus analysis? Testing differential models of cognitive style on entrepreneurial self-efficacy and the new venture creation process. Entrepreneurship: Theory and Practice, 33(2), 439-453.

Kickul, J., Wilson, F., Marlino, D., \& Barbosa, S. D. (2008). Are misalignments of perceptions and selfefficacy causing gender gaps in entrepreneurial intentions among our nation's teens? Journal of Small Business and Enterprise Development, 15(2), 321-335.

Kim, P. H., Aldrich, H. E., \& Keister, L. A. (2006). The impact of financial, human, and cultural capital on entrepreneurial entry in the United States. Small Business Economics, 27, 5-22.

Kolvereid, L. (1996). Predictions of employment status choice intentions. Entrepreneurship Theory and Practice, 21(1), 47-57.

Krueger, N. (1993). The impact of prior entrepreneurial exposure on perceptions of new venture feasibility and desirability. Entrepreneurship: Theory and Practice, 18(1), 5-21.

Krueger, N. F., \& Brazeal, D. V. (1994). Entrepreneurial exposure on perceptions of new venture feasibility and desirability. Entrepreneurship Theory and Practice, 19(3), 91-104.

Krueger, N., \& Dickson, P. R. (1994). How believing in ourselves increases risk-taking: Perceived. Decision Sciences, 25(3), 385-401.

Krueger, N., Reilly, M. D., \& Carsrud, A. L. (2000). Competing models of entrepreneurial intentions. Journal of Business Venturing, 15, 411-432.

Lee, S. H., \& Wong, P. K. (2004). An exploratory study of technopreneurial intentions: A career anchor perspective. Journal of Business Venturing, 19(1), 7-28.

Linan, F., \& Chen, Y. (2009). Development and cross-cultural application of a specific instrument to measure entrepreneurial intentions. Entrepreneurship: Theory and Practice, 593-617.

Littunen, H. (2000). Entrepreneurship and the characteristics of the entrepreneurial personality. International Journal of Entrepreneurial Behaviour \& Research, 6(6), 295-310.

Mayer, J. D., \& Salovey, P. (1997). What is emotional intelligence? In P. Salovey, \& D. Sluyter (Eds.), Emotional Development and Emotional Intelligence: Educational implications. New York: Basic Books, 3-34.

Mayer, J. D., Salovey, P., \& Caruso, D. R. (2000). Models of emotional intelligence. In R. J. Sternberg (Ed.), Handbook of Intelligence. Cambridge, England: Cambridge University Press, 396-420.

Nikolaou, I., \& Tsaousis, I. (2002). Emotional intelligence in the workplace: Exploring its effects on occupational stress and organizational commitment. The International Journal of Organizational Analysis, 10(4), 327-342.

Nunnally, J. C. (1978). Psychometric Theory. McGraw-Hill, New York.

O’Boyle, E. H., Humphrey, R. H., Pollack, J. M., Hawver, T. H., \& Story, P. A. (2011). The relation between emotional intelligence and job performance: A meta-analysis. Journal of Organizational Behavior, 32, 788-818.

Price, R. W. (2006). Entrepreneurship. Dubuque, IL: McGraw-Hill.

Rozell, E. J., Pettijohn, E. 1., \& Parker, S. (2002). An empirical evaluation of emotional intelligences: the impact of management development. Journal of Management Development, 21(4), 272-289.

Salovey, P., \& Mayer, J. D. (1990). Emotional intelligence. Imagination, Cognition and Personality, 9(3), 185-211.

Scherer, R. F., Adams, J. S., Carley, S. S., \& Wiebe, F. A. (1989). Role model performance effects on development of entrepreneurial career preference. Entrepreneurship: Theory \& Practice, 13, 5371.

Scherer, R. F., Brodzinski, J. D., \& Wiebe, F. A. (1990). Entrepreneur career selection and gender: A socialization approach. Journal of Small Business Management, 28(2), 37-44.

Scott, M., \& Twomey, D. (1988). The long-term supply of entrepreneurs: Students' career aspirations in relation to entrepreneurship. Journal of Small Business Management, 26(4), 5-13. 
Sequeira, J., Mueller, S. L., \& McGee, J. E. (2007). The influence of social ties and self-efficacy in forming entrepreneurial intentions and motivating nascent behavior. Journal of Developmental Entrepreneurship, 12(3), 275-293.

Shapero, A. (1982). Social dimensions of entrepreneurship. In C. Kent et al. (Eds.), The Encyclopedia of entrepreneurship, pp. 72-90. Englewood Cliffs, NJ: Prentice Hall.

Shaver, K. G., \& Scott, L. R. (1991). Person, process, choice: The psychology of new venture creation. Entrepreneurship Theory and Practice, 16(2), 23-45.

Shepherd, D. A. (2004). Entrepreneurship Students about Emotion and Learning from Failure. Academy of Management Learning \& Education.

Sheppard, B. H., Hartwick, J., Warshaw, P.R. (1988). The theory of reasoned action: A meta-analysis of past research with recommendations for modifications and future research. Journal of Consumer Research, 15, 325-343.

Thorndike, E. L. (1920). Intelligence and its uses. Harper's Magazine, 140, 227-235.

Walker, E. A., \& Webster, B. J. (2007). Gender, age and self-employment: Some things change, some stay the same. Women in Management Review, 22(2), 122-135.

Weisinger, H. (1998). Emotional Intelligence at Work: The untapped edge for success. San Francisco: Jossey-Bass.

Wood, R., \& Bandura, A. (1989). Social cognitive theory of organizational management. Academy of Management Review, 14(3), 361-384.

Zampetakis, L. A., Beldekos, P., \& Moustakis, V. S. (2009). "Day-to-day” entrepreneurship within organizations: The role of trait Emotional Intelligence and Perceived Organizational Support, European Management Journal, 27, 165-175.

Zhao, H., Seibert, S. E., \& Hills, G. E. (2005). The mediating role of self-efficacy belief in the development of entrepreneurial intentions. Journal of Applied Psychology, 90(6), 1265-1272. 